Pak. j. sci. ind. res. Ser. B: biol. sci. 201457 (1) 18-24

\title{
Effect of Plant Age on Cotton Leaf Curl Disease (CLCuD) in Relation to Environmental Conditions
}

\author{
Tariq Mahmood, Muhammad Tahir*, Hafiz Tariq Mahmood, Sabahat Hussain and \\ Dil Baugh Muhammad
}

Central Cotton Research Institute, Old Shujabad Road, Multan, Pakistan

(received July 9, 2012; revised July 19, 2013; accepted August 20, 2013)

\begin{abstract}
The effect of cotton leaf curl disease (CLCuD) and weather variables were studied using same genotypes of cotton, planted at 15 days interval during $15^{\text {th }}, 23^{\text {rd }}$ standard weeks of 2010-2011. On an average basis, the $15^{\text {th }}$ standard week planting showed, significantly, less disease incidence than all other sowing dates. The incidence increased as the sowing was delayed up to $23^{\text {rd }}$ standard weeks. Among the sowing dates, regardless of genotypes, disease incidence differed, significantly. The CLCuD boost up during $25^{\text {th }}$ to $29^{\text {th }}$ standard (2010) and $27^{\text {th }}$ to $31^{\text {st }}$ standard (2011) weeks of the year, regardless of sowing date and genotypes. Disease incidence was low during 2011 as compared to 2010 . The disease increased sharply during 2010 and gradually during 2011 . Average maximum $\left(34.8 \sim 39.8^{\circ} \mathrm{C}\right)$, minimum $\left(27.7 \sim 28.9^{\circ} \mathrm{C}\right)$ temperature and relative humidity (62 79\%) favoured CLCuD progression.
\end{abstract}

Keywords: cotton leaf curl disease, cotton cultivars, relative humidity, temperature

\section{Introduction}

Upland cotton (Gossypium hirsutum L.) is one of the important fibre and cash crops of Pakistan. Cotton occupies a unique position in textile world with millions of people engaged in its cultivation, processing and marketing etc.

The main reasons for low productivity of cotton is heavy attack by a number of insect-pests that results in various diseases starting from germination up to the harvest of crop. Among these diseases, cotton leaf curl virus disease (CLCuD) is the major reason for the decline in cotton production and productivity in Pakistan, especially in the Punjab. This disease is caused by cotton leaf curl virus (CLCuV) which belongs to begomovirus (Family Germiniviridae) transmitted in persistent manner by the vector, whitefly (Bemisia tabaci Gennadius). Characteristic symptom of the disease is upward or downward curling of leaves with thickened veins which is more pronounced on under side. The disease results in stunted plant growth with loss in yield (Hameed et al., 1994).

CLCuD was reported for the first time in Pakistan during 1967 near Multan. At that time disease was of minor importance and did not get much attention. After 1988 , the disease appeared in an epidemic form and

*Author for correspondence; E-mail: tahirsmart1@yahoo.com damaged the crop on about sixty thousand hectares with a loss of 0.3 billions bales in production (Mahmood et al., 1999). The geographic spread of CLCuD has increased tremendously and more than 7.7 million bales of cotton have been lost due to CLCuD from 1986 to 2002 (Akhtar et al., 2004).

Losses due to this disease depend upon the variety and sowing time of cotton crop (Tahir et al., 2004). Weather factors (individual and collectively) particularly temperature, relative humidity and rain fall influence the disease and vector (whitefly) population to great extent in host pathogen system. The hot and humid climate in north India during crop season is conducive for growth of host and the vector (Sharma et al., 2006). However, meager information is available on the role of climatic factors affecting vector population and disease development. The present studies were therefore, carried out to understand the role of environmental factors on the development of CLCuD.

\section{Materials and Methods}

The present investigations were designed to work out the effect of temperature and relative humidity and different planting dates on cotton varieties at research area of Central Cotton Research Institute (CCRI), Multan, Pakistan. 
Delinted seed of three genotypes viz., CIM-573, CIM496 and CIM-608 (2010) and CIM-554, CIM591 and CIM-608 (2011) were planted on $15^{\text {th }}, 17^{\text {th }}, 19^{\text {th }}, 21^{\text {st }}$, and $23^{\text {rd }}$ standard weeks of each year by dibbling method. The plants were spaced $75 \mathrm{~cm}$ row to row and $30 \mathrm{~cm}$ plant to plant distance. The experiment was conducted in split plot (main plot: planting time, subplot: genotypes) design with four replication. All other cultural practices were performed in standard fashions to optimise the seed cotton yield.

Observations on the incidence of CLCuD were recorded at 15 days interval starting from 30 days after planting and continued up to $35^{\text {th }}$ std., week.

Total numbers of plants showing leaf curl virus disease symptoms (upward curling with thickened veins on under side of leaf) were counted every time during observations. Plants with even a single leaf showing the symptoms of disease were counted as infected. The percentage disease incidence was counted by using following formula

$$
\text { Disease incidence }(\%)=\frac{\text { total plants }- \text { healthy plants }}{\text { total plants }} \times 100
$$

At the end of the season ( $35^{\text {th }}$ std., week) each and every plant was examined in the field and different grades/ scales were allotted to them according to the level of infection in disease plants as described by Akhtar and Khan (2002). The rating scales are given in Table 1.

The percentage of disease index was calculated by using the following formula
Disease index $(\%)=\frac{\begin{array}{c}\text { summation of } \\ \text { all disease ratings }\end{array}}{\text { total plants }} \times \frac{100}{\text { maximum grade }}$

The data on environmental variables were obtained from Meteorological Department, Central Cotton Research Institute, Multan, Pakistan. Data for fortnightly progression of disease incidence were calculated and compared with environmental parameters (maximum, minimum temperature $\&$ relative humidity) of that period of each year separately. The pooled data for both years were first analysed by simple regression. The disease index were subjected to standard statistical analysis (Steel et al., 1996) and the means were compared using DMR/LSD test $(\mathrm{P}=005)$.

\section{Results and Discussion}

The results of incidence of CLCuD monitored (fortnightly interval) right from 30 days after planting for all planting dates in each year are given in Table 2-3.

Progression of disease. Results reveal that expression of $\mathrm{CLCuD}$ and its progression during the crop seasons of (2010 and 2011) differed greatly with planting dates. Averaged across varieties, minimum incidence of disease (1.7\%) was recorded at day 45 after planting and increased upto $11.9 \%$ at day 60 after planting. The disease boosted upto $82 \%$ at day 120 after planting on that crop planted on $15^{\text {th }}$ std., week of the year.

The infection level was $9.5 \%$ at day 45 and attained its maximum $(98.2 \%)$ at day 105 after planting on crop planted on $17^{\text {th }}$ std., week of the year. However, incidence

Table 1. Disease rating scales on the basis of intensity of CLCuD for its index

\begin{tabular}{|c|c|c|c|}
\hline Symptoms & $\begin{array}{l}\text { Rating } \\
\text { scale }\end{array}$ & Symptoms & $\begin{array}{l}\text { Rating } \\
\text { scale }\end{array}$ \\
\hline Complete absence of symptoms & 0 & $\begin{array}{l}\text { Large groups of veins } \\
\text { involved and curling or top } \\
\text { of the plant affected }\end{array}$ & 4 \\
\hline $\begin{array}{l}\text { Few small scattered vein } \\
\text { thickening }\end{array}$ & 1 & $\begin{array}{l}\text { All veins involved and } \\
\text { severe curling or half of the } \\
\text { plant affected }\end{array}$ & 5 \\
\hline Small scattered vein thickening & 2 & $\begin{array}{l}\text { All veins involved and } \\
\text { severe curling and stunted } \\
\text { plant or whole of the plant } \\
\text { affected and stunting }\end{array}$ & 6 \\
\hline $\begin{array}{l}\text { Vein thickening involving } \\
\text { small groups of veins }\end{array}$ & 3 & Enations & $\mathrm{E}$ \\
\hline
\end{tabular}


Table 2. Incidence of CLCuD as influenced by planting dates and strain during 2010

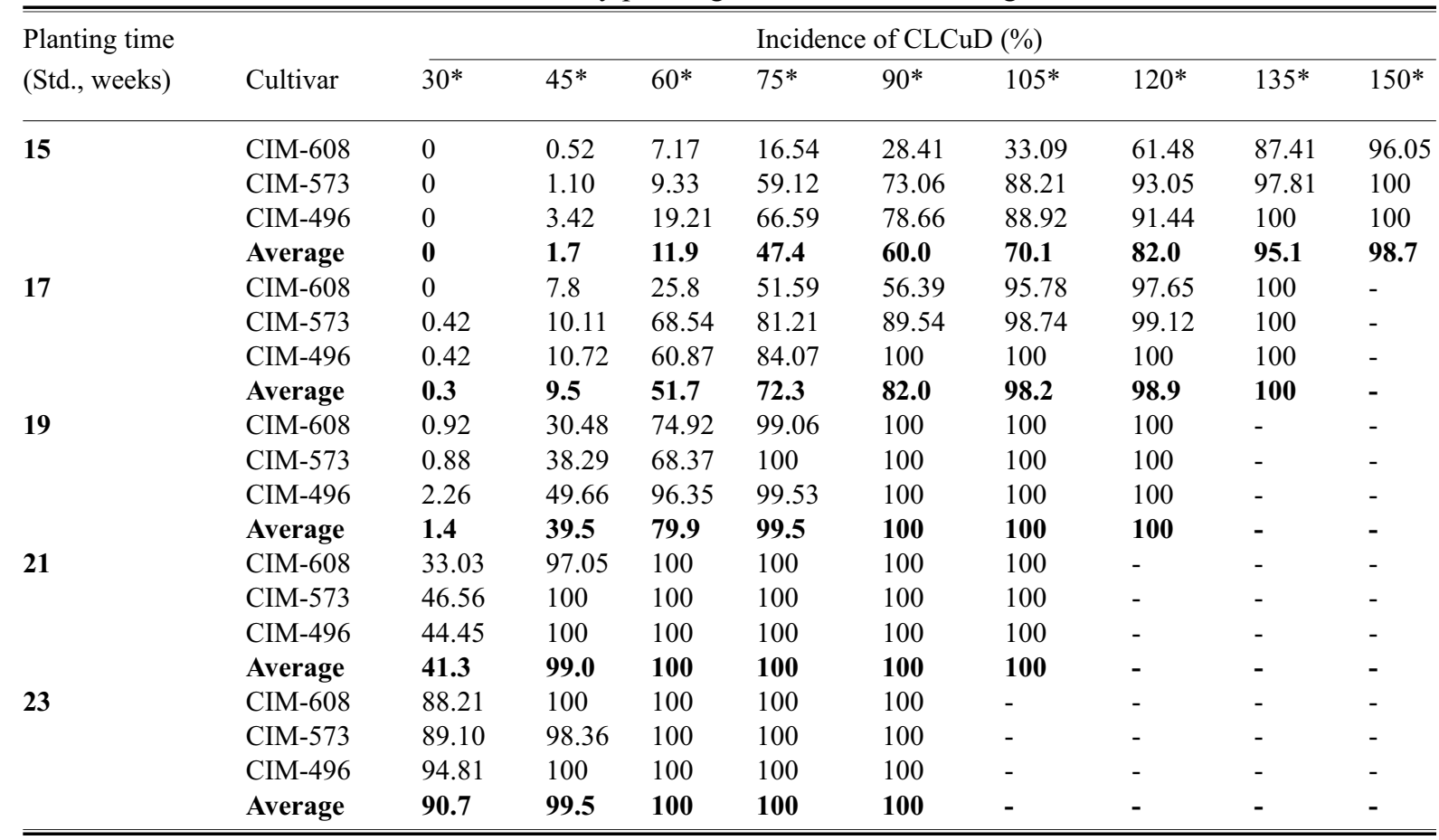

* = days after planting.

Table 3. Incidence of CLCuD as influenced by planting dates and strain during 2011

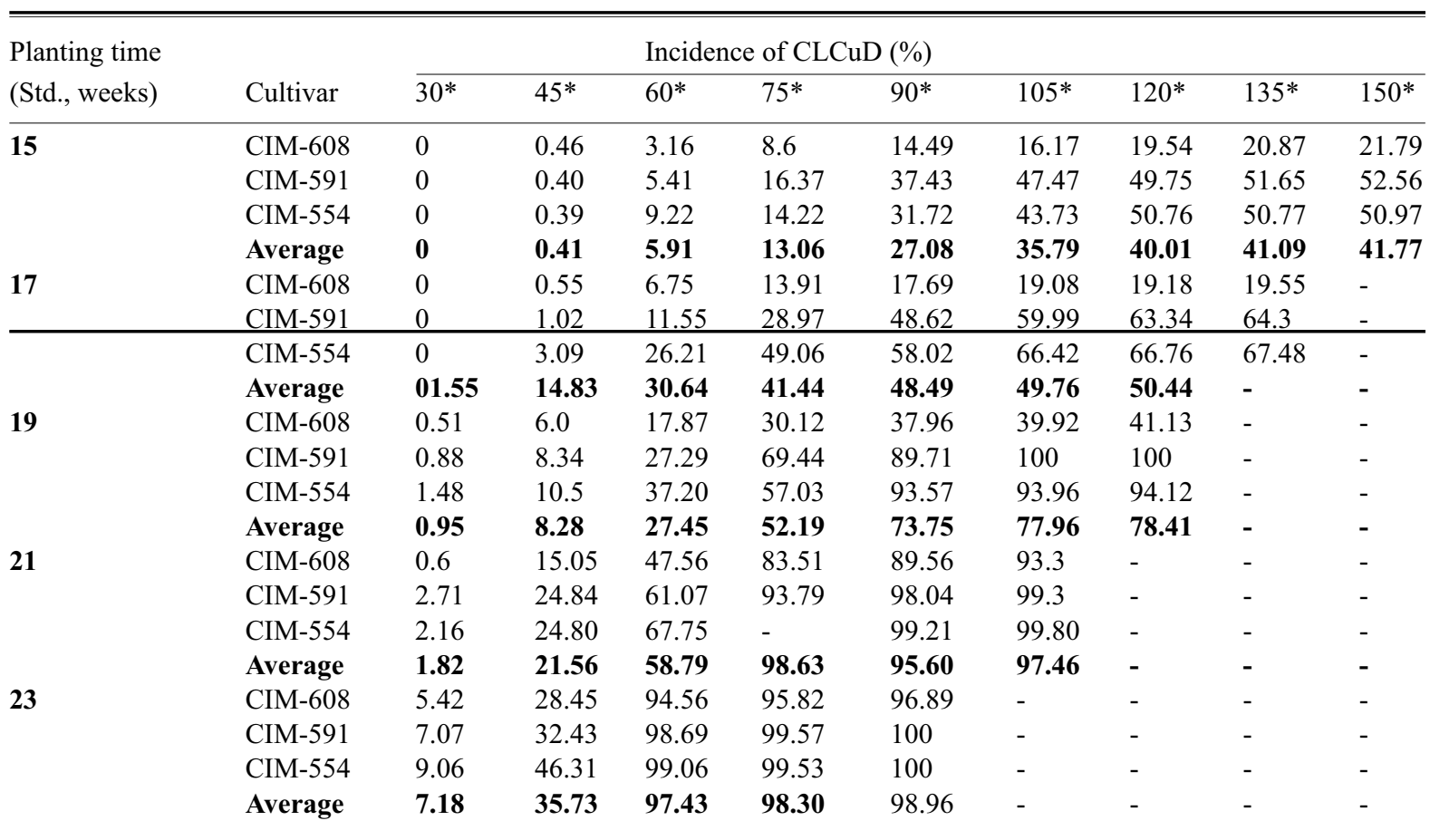

* = days after planting.

of $\mathrm{CLCuD}(39.5 \%)$ of day 45 and reached to its maximum level $(99.5 \%)$ at day 75 after planting on crop planted on $19^{\text {th }}$ std., week of the year. The incidence of the disease was $41.3 \%$ at day 30 and reached to maximum (99\%) at day 45 after planting on crop planted on 21 std., week of the year. Further more crops planted on $23^{\text {rd }}$ std., week of the year fell prey to $\mathrm{CLCuD}$ to 90.7\% within 30 days after planting and to maximal 
(99.5\%) with in next 15 days (Table 2). Data revealed that the incidence of disease increased and period decreased (days after planting) as the planting time was increased (Table 2).

Averaged across varieties, disease started at low level $(0.41 \%)$ at day 45 after planting and reached upto $5.91 \%$ at day 60 after planting. With the advancement of age, the incidence progressed gradually to $40.01 \%$ within next 60 days, on that crop planted on $15^{\text {th }}$ std., week of the year. The infection level was 14.83 at day 60 and attained it maximum (48.4\%) at day 105 after planting on crop planted on $17^{\text {th }}$ std., week of the year. However, incidence of $\mathrm{CLCuD}$ was $8.28 \%$ at day 45 and reached to its maximum level $78.4 \%$ within rest days as crop planted 19 std., week of the year. The incidence of disease start from $1.82 \%$ at day 30 and reached upto $(91.9 \%)$ at day 75 after planting on crop planted $21^{\text {st }}$ std., week of the year. Furthermore, the crop planted $23^{\text {rd }}$ std., week of the year fell prey to CLCuD to $97.4 \%$ with in 60 days after planting, which is $50 \%$ period less and incidence double than those crop planted on $17^{\text {th }}$ std., week of the year (Table 3). Similar findings were made by Tahir et al. (2004) and Khan et al. (1988). They concluded that maximum incidence was recorded in June planting $\left(21^{\text {st }}\right.$ std., week) and increased rapidly in the first week of August (29 ${ }^{\text {th }}$ std., week) in all planting dates.

Effect of planting date. One of the most important agronomic considerations for growers to optimise yield and quality is to select an appropriate planting time for cotton crop. Choosing the best time for planting in a particular region can often be difficult as it is a decision that must strike a balance between planting too early and too late and enduring problems of different pest and diseases. Planting too early and too late makes the crop susceptible to different diseases, like CLCuD. Data on the effect on planting on the disease index of CLCuD (Table 2-3) revealed that among sowing dates regardless of genotypes, disease incidence differed significantly. The CLCuD boost up during $25^{\text {th }}$ to $29^{\text {th }}$ std., (2010) and $27^{\text {th }}$ to $31^{\text {st }}$ std., (2011) weeks of the year regardless of sowing dates and genotypes.

Averaged across cultivars, minimum disease index of CLCuD were recorded on $35^{\text {th }}$ std., week of the year (150 days after planting) on crop planted on $15^{\text {th }}$ std., week of the year (2010). Whereas, in other planting, data showed that no difference in disease index was observed. (Fig. 1). Averaged across cultivations, minimum disease index of CLCuD was recorded on

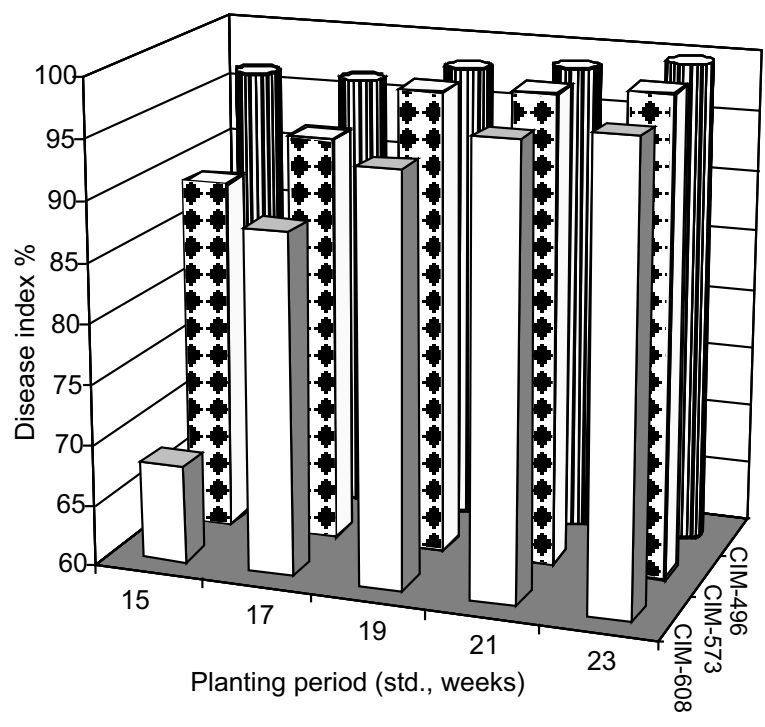

Fig. 1. Effect of CLCuD index as affected by different planting dates during 2010 .

crop planted on $15^{\text {th }}$ std. and $17^{\text {th }}$ std., week compared with crop planted on $19^{\text {th }}$ std., week of the year (2011). A little difference of disease index was recorded on crop planted during $21^{\text {st }}$ and $23^{\text {rd }}$ std., week of the year (Fig. 2). According to Sharma et al. (2006), the disease incidence increases rapidly between the mid of June to the last week of July $\left(25^{\text {th }}-31^{\text {st }}\right.$ std., week). Ghazanfar et al. (2007) also stated that sowing even earlier to $15^{\text {th }}$ May $\left(19^{\text {th }}\right.$ std., week) may have more effect on reduction in disease incidence which needs to be tested.

Varieties effects. The responses of varieties of cotton crop species toward the attack of its different pathogens are different. Some varieties display tolerant and others exhibit susceptible response. The maximum disease index of CLCuD was recorded on CIM-496 (97\%), followed by CIM-573 (95\%) and CIM-608 (89\%) respectively, irrespective of the planting dates for the year 2010 (Fig. 1). On the basis of disease incidence (Table 2) and CLCuD index (Fig. 1) the strain CIM608 showed some tolerance against the disease as compared to other varities/strains when planted on $15^{\text {th }}$ std., week of the year. Whereas, in other planting, data showed that no difference in disease index was observed in all cultivars.

Averaged across planting dates, minimum disease index (33\%) was recorded on cultivar CIM-608 followed by CIM-591 (59\%) and CIM-554 (60\%), respectively, during the year 2011 (Fig. 2). However, there was little difference of incidence and disease index when planted 


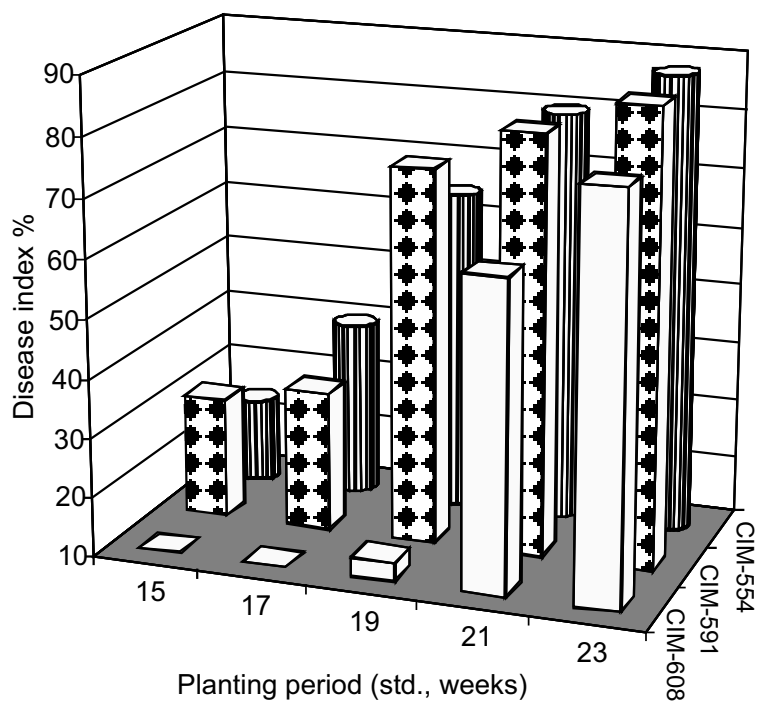

Fig. 2. Effect of CLCuD index as affected by different planting dates during 2011.

on $21^{\text {st }}$ to $23^{\text {rd }}$ std., week of the year as well as with the comparison of other strains/varieties. The cultivars CIM-554 and CIM-591 showed no effect on the reduction of disease index on any planting dates.

It is concluded from the two years studies on sowing dates in relation to CLCuD, the CIM-608 showed comparatively less incidence of disease when planted between $15^{\text {th }}$ to $17^{\text {th }}$ std., weeks of the year. Whereas, planting during $19^{\text {th }}$ std., week of the year or late, it was heavily attacked by CLCuD (Table 4). It may be suggested that to plant the cultivar (CIM-608) before $19^{\text {th }}$ std., week of the year to get maximum yield due to less disease incidence.

These findings are similar to that of Tahir et al. (2004) who found that in cotton cultivars under trial, the incidence was more on CIM-496 as compared to others. Akhtar et al. (2004) found that the age related to susceptibility to CLCuD was more apparent in late planting. Maximum increase in disease incidence occurred at 6 weeks after sowing. The incidence of different viral and fungal diseases is also influenced by altering the date of sowing as reported by Mirza (1992) and Singh et al. (1989).

Effect of weather parameters. The fortnightly increase in the disease of both years along with the environmental parameters of that period is given in Table. 5-6.

On an average basis of planting dates the fortnightly increase of the maximum disease started from $25^{\text {th }}-29^{\text {th }}$ std., week of the year (2010) during which period the range of maximum temperature was 35.5 to

Table 4. Incidence of CLCuD as influenced by planting dates on cultivar CIM-608 during 2010-11

\begin{tabular}{|c|c|c|c|c|c|c|c|c|c|}
\hline \multirow{2}{*}{$\begin{array}{l}\text { Planting time } \\
\text { (Std., weeks) }\end{array}$} & \multicolumn{9}{|c|}{ Incidence of CLCuD (\%) } \\
\hline & $30^{*}$ & $45^{*}$ & $60^{*}$ & $75^{*}$ & $90 *$ & $105^{*}$ & $120^{*}$ & $135^{*}$ & $150^{*}$ \\
\hline 15 & 0 & 0.49 & 5.16 & 12.5 & 21.4 & 24.6 & 40.5 & 54.1 & 58.92 \\
\hline 17 & 0 & 4.1 & 16.2 & 41.7 & 37.0 & 57.0 & 57.4 & 59.7 & $\hat{\mathrm{E}}$ \\
\hline 19 & 0.7 & 18.2 & 46.3 & 64.5 & 68.9 & 69.6 & 70.5 & $\hat{\mathrm{E}}$ & $\hat{\mathrm{E}}$ \\
\hline 21 & 16.8 & 56.0 & 73.7 & 91.7 & 94.7 & 96.6 & $\hat{\mathrm{E}}$ & $\hat{\mathrm{E}}$ & $\hat{\mathrm{E}}$ \\
\hline 23 & 46.8 & 64.2 & 97.2 & 98.4 & - & - & - & - & - \\
\hline
\end{tabular}

* = days after planting.

Table 5. Relationship between fortnightly increase in CLCuD with weather parameters during 2010

\begin{tabular}{llllllllll}
\hline \hline $\begin{array}{l}\text { Planting time } \\
\text { (Std., weeks) }\end{array}$ & \multicolumn{7}{c}{ Fortnightly increase on std., weeks } \\
\cline { 2 - 10 } & 19 & 21 & 23 & 25 & 27 & 29 & 31 & 33 & 35 \\
\hline $\mathbf{1 5}$ & 0 & 1.7 & 10.2 & 35.5 & 12.6 & 10.0 & 11.9 & 13.1 & 0.6 \\
$\mathbf{1 7}$ & - & 0.3 & 9.3 & 42.2 & 20.6 & 9.7 & 16.2 & 0.8 & 0.4 \\
$\mathbf{1 9}$ & - & - & 1.4 & 38.1 & 40.4 & 19.7 & 0.5 & 0.0 & 0.5 \\
$\mathbf{2 1}$ & - & - & - & 41.3 & 57.7 & 1.0 & 0.0 & 0.0 & 0.0 \\
$\mathbf{2 3}$ & - & - & - & - & 90.7 & 8.7 & 0.5 & 0.0 & 0.0 \\
Average & - & - & $\mathbf{6 . 9}$ & $\mathbf{3 9 . 2}$ & $\mathbf{4 4 . 0}$ & $\mathbf{9 . 8}$ & $\mathbf{5 . 8}$ & $\mathbf{2 . 8}$ & $\mathbf{0 . 3}$ \\
Max. ${ }^{\circ} \mathrm{C}$ & 39.9 & 42.2 & 38.1 & 39.8 & 37.0 & 35.5 & 33.5 & 34.4 & 37.9 \\
Min. ${ }^{\circ} \mathrm{C}$ & 24.5 & 26.5 & 27.7 & 28.9 & 28.8 & 28.9 & 27.6 & 27.1 & 26.7 \\
Difference & 15.4 & 15.7 & 10.4 & 10.9 & 8.2 & 6.6 & 5.9 & 7.3 & 8.2 \\
RH\% & 49.0 & 40.5 & 52.0 & 62.5 & 68.7 & 79.6 & 89.6 & 82.7 & 80.9 \\
\hline \hline
\end{tabular}


Table 6. Relationship between fortnightly increases in CLCuD with weather parameters during 2011

\begin{tabular}{|c|c|c|c|c|c|c|c|c|c|}
\hline \multirow{2}{*}{$\begin{array}{l}\text { Planting time } \\
\text { (Std., weeks) }\end{array}$} & \multirow[b]{2}{*}{19} & \multirow[b]{2}{*}{21} & \multirow[b]{2}{*}{23} & \multicolumn{5}{|c|}{ Fortnightly increase on std., weeks } & \multirow[b]{2}{*}{35} \\
\hline & & & & 25 & 27 & 29 & 31 & 33 & \\
\hline 15 & 0 & 0.4 & 5.5 & 7.1 & 15.0 & 7.9 & 4.2 & 1.1 & 0.6 \\
\hline 17 & - & 0.0 & 1.6 & 10.3 & 15.8 & 10.8 & 7.1 & 1.3 & 0.4 \\
\hline 19 & - & - & 1.0 & 7.3 & 22.2 & 24.7 & 21.6 & 3.9 & 0.5 \\
\hline 21 & - & - & - & 1.8 & 19.7 & 37.2 & 33.2 & 3.5 & 2.0 \\
\hline 23 & - & - & - & - & 7.2 & 28.5 & 61.7 & 1.1 & 0.6 \\
\hline Average & - & - & - & 6.6 & 16.0 & 21.8 & 25.5 & 2.2 & 0.8 \\
\hline Max. ${ }^{\circ} \mathrm{C}$ & 39.8 & 41 & 40 & 38.6 & 36.6 & 36.5 & 34.8 & 34.3 & 32.3 \\
\hline $\operatorname{Min} .{ }^{\circ} \mathrm{C}$ & 25.3 & 28.4 & 28.4 & 30.2 & 28.5 & 28.8 & 28.8 & 27.4 & 26.7 \\
\hline Difference & 14.5 & 12.6 & 11.6 & 8.4 & 8.1 & 7.7 & 6.0 & 6.9 & 5.6 \\
\hline RH\% & 52.6 & 53.4 & 54.6 & 67.8 & 72 & 76.1 & 75.4 & 82.5 & 56.8 \\
\hline
\end{tabular}

$39.8{ }^{\circ} \mathrm{C}$ with R.H from 62.5 to $79.6 \%$. The fortnightly increase of the disease remains negligible or low before $25^{\text {th }}$ std., week because during those days the temperature remained high with low R.H and after $29^{\text {th }}$ std., week due to low temperature with high relative humidity, irrespective of planting dates; whereas the incidence remained low (during $25^{\text {th }}-29^{\text {th }}$ std., weeks of the year) on that crop planted on $15^{\text {th }}-17^{\text {th }}$ std., week of the year as compared to other planting dates (Table 5).

On an averaged basis of planting dates the maximum fortnightly increase of the disease starts from $27^{\text {th }}-31^{\text {th }}$ std., week of the year (2011). Among environmental parameters the maximum temperature range was 34.8$38.6^{\circ} \mathrm{C}$, minimum temperature, $28.5-28.8^{\circ} \mathrm{C}$ with relative humidity $72.0-76.1 \%$ during the above mentioned period. The fortnightly increase of the disease remained low up to $25^{\text {th }}$ std., week of the year and same conditions were found after $31^{\text {st }}$ std., week of the year (Table 6).

It is clear that $\mathrm{CLCuD}$ increased rapidly during the period $25^{\text {th }}$ to $27^{\text {th }}$ std., week of the year 2010 , whereas, the disease gradually increased during the $29^{\text {th }}$ to $31^{\text {th }}$ std., week of the year 2011. If it is compared with the weather parameters it indicates that the maximum temperature was high, minimum temperature remained constant with relative humidity $62-79 \%$ in the year 2010 as compared to 2011 during $25^{\text {th }}$ to $31^{\text {th }}$ std., week of the year.

It is concluded that the disease does not express its symptoms if the temperature is greater than $40{ }^{\circ} \mathrm{C}$ and less than $50 \%$ of relative humidity during the early season of the crop. During the end of the season the disease also does not exhibit its symptoms if temperature is less than $34{ }^{\circ} \mathrm{C}$ with greater than $80 \%$ relative humidity. The results are in accordance with the findings of Sherma et al. (2006). In this study it is concluded that the disease was highly influenced by mean temperature and morning humidity. The morning relative humidity and mean temperature explained the variability in disease incidence.

\section{Conclusion}

Planting time plays an important role to get maximum cotton yield. The age of cotton plant was directly related of CLCuD susceptibility in late planting. Among cultivars the strain CIM-608 showed comparatively less incidence of CLCuD when planted between $15^{\text {th }}$ to $17^{\text {th }}$ std., weeks of each year. It is suggested that CIM-608 may be cultivated before $19^{\text {th }}$ std., week of the year to get less disease incidence. The CLCuD increased rapidly, when the weather parameters remain average i.e., maximum temperature 34.8 to $39.8{ }^{\circ} \mathrm{C}$, minimum temperature 27.7 to $28.9^{\circ} \mathrm{C}$, and relative humidity 62 to $79 \%$. In case of early planting, plants had attained strong vigour before prevalence of these environmental conditions so plants were less affected by CLCuD as compared to late planting. In late planting, plants were week and tender at these weather phases and caused more $\mathrm{CLCuD}$ infection.

One of the tools used in reducing environmental risks and increasing the possibilities of profitable yield is cultivar development through breeding and genetics.

\section{References}

Akhtar, K.P., Hussain, M., Khan, A.I., Haq, M.A., Iqbal, M.M. 2004. Influence of plant age, whitefly population and cultivar on infection of cotton plants by cotton leaf curl virus $(\mathrm{CLCuV})$ in Pakistan. Field Crop Research, 86: 15-21.

Akhtar, K.P., Khan, S.I. 2002. Modified scale for the 
assessment of cotton leaf curl virus (CLCuV). Pakistan Journal of Phytopathalogy, 14: 88-90.

Ghazanfar, S., Sahi, T., Ilyas, M.B., Randhawa, M.A. 2007. Influence of sowing dates on $\mathrm{CLCuV}$ incidence in some cotton varieties. Pakistan Journal of Phytopathalogy, 19: 177-180.

Hameed, S., Khalid, S., Haq, E.U., Hashmi, A.A. 1994. Cotton leaf curl disease in Pakistan caused by a whitefly transmitted geminiviruses. Pant Diseases, 78: 529.

Khan, M., Soomro, A., Arain, A. 1988. Effect of sowing dates on the yield components of some cotton genotypes. Pakistan Cotton, 32: 22-29.

Mirza, M.S. 1992. Virus problem in cotton and its control. In: Proceedings of National Seminar on Cotton Production, at Ayub Agriculture Research Institute, Faisalabad, (April 20, 1992), Pakistan.

Mahmood, T. 1999. Cotton leaf curl virus disease and its status in Pakistan. In: Proceedings of ICACCCRI, Regional Consultation on Insecticide
Resistance Management in Cotton, pp., 234-244, Central Cotton Research Institute, (June $28^{\text {th }}$ to $1^{\text {st }}$ July, 1999), Multan, Pakistan.

Sharma, J., Beniwal, J., Kumar, A. 2006. Influence of weather variable on curl virus $(\mathrm{CLCuV})$ disease in cotton (Gossypium hirsutum). Journal of Cotton Research and Development, 20: 282-285.

Singh, B., Mahant, S., Singh, M. 1989. Control of yellow vein mosaic of okra by checking its vector (whitefly) through adjusting dates of sowing insecticidal application and crop barrier. Indian Journal of Virolgy, 5: 61-66.

Steel, R.G.D., Torrie, T.H., Dickey, D. 1996. Principles and Procedures of Statistics: A Biometrical Approach, 672 pp., $3^{\text {rd }}$ edition, McGraw Hill Book Co., New York, USA.

Tahir, M., Mahmood, T., Mahmood, H.T., Sabahat, H. 2004. Effect of sowing dates on incidence of cotton leaf curl virus on different cultivars of cotton. Plant Pathology Journal, 3: 61-64. 